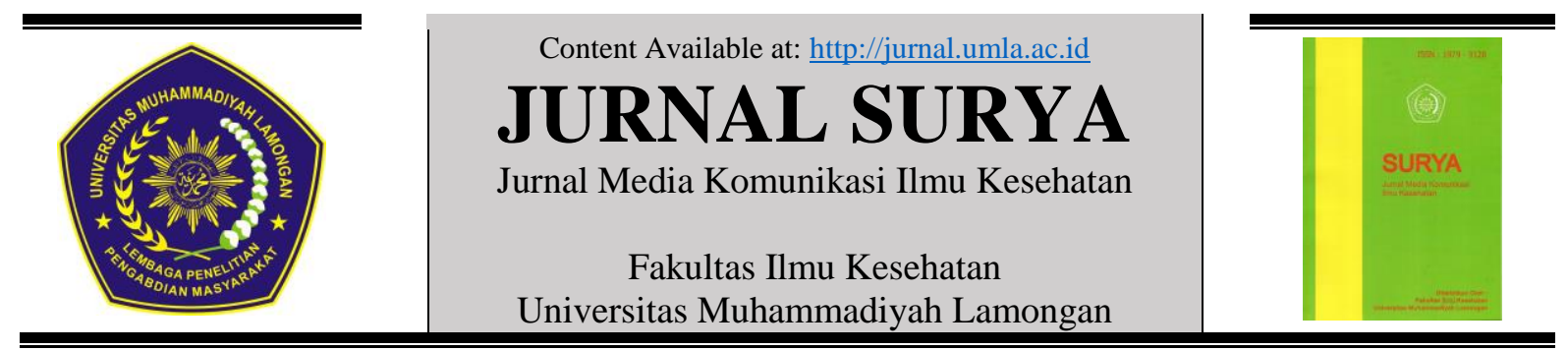

\title{
Gambaran Pengetahuan Tentang Inisiasi Menyusu Dini (IMD) Ibu Hamil Trimester II Dan III di RSI Nasrul Ummah Lamongan
}

Lailatul Fadliyah ${ }^{1}$, Fadlilatul Qo 'imah ${ }^{2}$

${ }^{1,2}$ Prodi D-III Keperawatan Fakultas Vokasi Universitas Airlangga

\section{ARTIKEL INFO}

Article History:

SM at 09-12-2019

$R$ V at 10-12-2019

$P B$ at 24-12-2019

\section{Kata Kunci:}

Pengetahuan

Inisiasi Menyusu Dini (IMD)

Bumil TM II dan III.

Korespondensi Penulis: fadliyahlaila@yahoo.co.id

\section{ABSTRAK}

Background: Air Susu Ibu (ASI) merupakan makanan yang terbaik bagi bayi, terutama pada bulan-bulan pertama hidupnya. Asi mengandung semua zat gizi untuk membangun dan menyediakan energi yang diperlukan oleh bayi (Novianti, 2014). Keberhasilan pemberian ASI diawali dengan segera melakukan prosedur Inisiasi Menyusu Dini (IMD). Pada survey awal ditemukan dari 3 ibu pasca persalinan yang melakukan IMD 2 diantaranya tehniknya kurang tepat yaitu bayi langsung diteteki tanpa bayi mencapai puting susu ibu sendiri.

Objectives: Tujuan dari penelitian ini adalah mengetahui Gambaran Pengetahuan Ibu Hamil Trimester II dan III Tentang Inisiasi Menyusu Dini (IMD) di RSI Nasrul Ummah Lamongan

Design: Penelitian ini menggunakan desain deskriptif, dengan sampel sebanyak 24 responden. Sampling yang digunakan yaitu consecutif sampling. Pengumpulan data dengan kuesioner tertutup. Pengolahan data dan analisa data dengan editing, scoring, coding, tabulating dan disajikan dalam bentuk narasi kemudian dilakukan penarikan kesimpulan.

Results: Berdasarkan hasil penelitian didapatkan sebagian besar $(54,1 \%)$ mempunyai pengetahuan kurang, hampir setengahnya 41,7 pengetahuan cukup dan sebagian kecil berpengetahuan baik tentang Inisiasi Menyusu Dini (IMD). Conclusions: Rujukan dari peilitian ini untuk meningkatkan pengetahuan ibu tentang Inisiasi Menyusu Dini (IMD) maka petugas / perawat hendaknya rutin melakukan promosi tentang Inisiasi Menyusu Dini (IMD) terutama saat ibu dan suami atau keluarga kunjungan ke layanan kesehatan. Penyebaran brosur dan leaflet agar mudah dipelajari oleh masyarakat. Praktik melakukan IMD langsung ke klien ataupun pemutaran video diharapkan bisa meningkatkan cakupan dan pengetahuan ibu tentang keberhasilan Inisiasi Menyusu Dini (IMD). 
PENDAHULUAN

Asi merupakan makanan yang terbaik bagi bayi terutama pada bulan awal kehidupannya karena mengandung zat gizi untuk membangun dan menyediakan energi yang diperlukan oleh bayi (Novianti, 2014). Pemberian Asi merupakan satu upaya untuk membentuk generasi sehat, cerdas, dan berkualitas, demi masa depan dirinya, keluarga, masyarakat dan Negara (Iis, 2010). Keberhasilan pemberian Asi diawali dengan segera melakukan prosedur Inisiasi Menyusu Dini (IMD) yang di promosikan sebagai metode ideal pemberian nutrisi bayi dikarenakan banyak bermanfaat bagi ibu dan bayi. Menyusui bayi yang optimal harus dimulai segera yaitu dalam satu jam pertama kelahiran, kemudian dilanjutkan dengan pemberian Asi Ekslusif selama 6 bulan (Lau Y, 2015).

Inisiasi Menyusu Dini (IMD) merupakan faktor yang terpenting sebagai penentu keberhasilan Asi ekslusif. Dengan Inisiasi Menyusu Dini (IMD) produksi Asi akan terstimulasi sejak dini, juga dapatt merangsang pengeluaran placenta dan mempercepat pengeluaran Asi (Tamara, 2011). Pilar utama dalam proses menyusui adalah IMD (early initiation) atau permulaan menyusu dini adalah bayi mulai menyusu sendiri segera setelah lahir. Cara bayi melakukan inisiasi menyusu dini dinamakan the breast crawl atau merangkak mencari payudara setelah bayi dikeringkan dan diletakkan pada di perut ibu dengan kontak kulit ke kulit (Saleha, 2009).

Data Unicef tahun 2018 hanya dua dari lima bayi yang melakukan Inisiasi Menyusu Dini (IMD) dalam satu jam pertama kehidupannya. Negara Eropa timur dan Asia Tengah sebesar $56 \%$, Asia selatan $40 \%$, Asia Timur dan pasifik sebesar $32 \%$, Africa selatan $65 \%$. Indonesia tahun 2017 prosentase bayi lahir yang dilakukan Inisiasi Menyusu Dini (IMD) 73,06 \%, angka ini sudah melampaui target renstra $44 \%$. Data dari RSI Nasrul Ummah Lamongan tahun 2018 bayi yang mendapatkan Inisiasi Menyusu Dini (IMD) sebesar $90 \%$ dan 2 dari 3 bayi yang dilakukan Inisiasi Menyusu Dini (IMD) tehniknya masih kurang tepat yaitu bayi langsung diteteki tanpa bayi mencapai puting susu ibu sendiri.
Pengetahuan ibu tentang Inisiasi Menyusu Dini (IMD) terutama manfaatnya sangat penting dalam keberhasilan menyusui bayi. Seringkali ibu memiliki pemahaman yang tidak benar misalkan ibu tidak perlu meneteki bayi karena Asi belum keluar atau air susu yang keluar pertama kali dan berwarna kuning adalah kotoran dan basi (Adam, 2016). Sikap ibu yang menolak pelaksanaan Inisiasi Menyusu Dini (IMD) berhubungan erat dengan pengetahuan yang dimiliki ibu.

Beberapa rumah sakit menerapkan sistem perawatan yang terpisah antara ibu dan bayi. Sarana kesehatan yang kurang memadai dalam memberikan peluang ibu melakukan Inisiasi Menyusu Dini (IMD) dapat memberikan kontribusi yang cukup tinggi dalam kegagalan menyusui. Dukungan petugas kesehatan dan keluarga penting dalam membantu proses ibu belajar memberikan Asi pertama kali pada bayinya (Mahmud, 2013)

Inisiasi Menyusu Dini (IMD) pada saat setelah bayi lahir akan meningkatkan reflek menyusu secara optimal sehingga berdampak memberikan sumber makanan bagi bayi, mencegah terjadinya hipotermi, bayi merasa tenang, menurunkan kejadian hipoglikemia, meningkatkan kekebalan tubuh bayi, dan meningkatkan bounding antara ibu dan bayi.

Dampak yang bisa timbul akibat tidak dilakukan Inisiasi Menyusu Dini (IMD) antara lain produksi Asi terhambat karena oksitocin yang berpengaruh terhadap produksi Asi tidak ada. Hisapan bayi pada saat menyusu pada payudara ibu akan merangsang pengeluaran hormon oksitocin. Fungsi lain hormon oksiticin adalah merangsang kontraksi uterus yang selanjutnya berakibat positif yaitu mengurang perdarahan pada ibu nifas. (Saleha, 2009).

Penatalaksanaan Inisiasi Menyusu Dini (IMD) pada ibu nifas sebaiknya disosialisasikan pada saat sebelum melahirkan atau ibu kondisi hamil, health education mutlak diperlukan untuk berhasilnya pelaksanaan Inisiasi Menyusu Dini (IMD) secara benar. Keluarga terdekat atau yang berpengaruh terhadap perilaku ibu hamil diharapkan mampu mendukung pelaksanaan Inisiasi Menyusu Dini (IMD). Peran petugas kesehatan untuk mensosialisasikan Inisiasi Menyusu Dini (IMD) pada masyarakat perlu 
dukungan dari berbagai fihak demi keberhasilan menyusui.

Dari uraian di atas, maka penulis tertarik melakukan penelitian tentang pengetahuan ibu hamil trimester II dan III tentang Inisiasi Menyusu Dini (IMD).

\section{METODE}

Jenis penelitian ini adalah diskriptif dengan menggunakan metode consecutive sampling, populasinya adalah semua ibu hamil yang berkunjung ke poli kandungan RSI Nasrul Ummah Lamongan sebanyak 36 ibu hamil. Populasi yang memenuhi kriteria inklusi sebanyak 24 resonden. Variabel penelitian yakni Pengetahuan Tentang Inisiasi Menyusu Dini (IMD) pada ibu hamil trimester II dan III. Pengumpulan data dengan menggunakan lembar kuesioner dan pengolahan data melalui proses editing, scoring, coding, tabulating dan disajikan dalam bentuk narasi kemudian dilakukan penarikan kesimpulan.

\section{HASIL PENELITIAN}

Tabel 1 Distribusi Responden Berdasarkan Umur di RSI Nasrul Ummah Lamongan tahun 2019.

\begin{tabular}{llcc}
\hline No & Pendidikan & F & \% \\
\hline 1. & 20-25 tahun & 8 & 33,3 \\
2. & 26-30 tahun & 9 & 37,5 \\
3. & 31-35 tahun & 4 & 16,7 \\
4. & 36-40 tahun & 3 & 12,5 \\
\hline & Total & $\mathbf{2 4}$ & $\mathbf{1 0 0}$ \\
\hline
\end{tabular}

Dari tabel 1. Menunjukkan bahwa hampir setengah responden berumur 26-30 tahun, sebagian kecil berumur 36-40 tahun.

Tabel 2 Distribusi responden berdasarkan pendidikan di RSI Nasrul Ummah Lamongan tahun 2019.

\begin{tabular}{llcc}
\hline No & Pekerjaan & F & \% \\
\hline 1. & SMP/MTS & 4 & 16,7 \\
2. & SMA/Sederajat & 11 & 45,8 \\
3. & PT & 9 & 37,5 \\
\hline & Total & $\mathbf{2 4}$ & $\mathbf{1 0 0}$ \\
\hline
\end{tabular}

Tabel 2. Menunjukkan bahwa hampir sebagian responden berpendidikan SMA/SMK/ MA dan sebagian kecil SMP/MTS.
Tabel 3 Distribusi Responden Berdasarkan Pekerjaan di RSI Nasrul Ummah Lamongan tahun 2019.

\begin{tabular}{llcc}
\hline No & Pekerjaan & F & \% \\
\hline 1. & IRT & 10 & 41,7 \\
2. & PNS & 4 & 16,7 \\
3. & Swasta & 5 & 20,8 \\
4. & Wiraswasta & 4 & 16,7 \\
5. & Mahasiswa & 1 & 4,1 \\
\hline & Total & $\mathbf{2 4}$ & $\mathbf{1 0 0}$ \\
\hline
\end{tabular}

Tabel 3. Menunjukkan bahwa hampir sebagian sebagai ibu rumah tangga dan sebagian kecil sebagai mahasiswa.

Tabel 4 Distribusi Pengetahuan Tentang Inisiasi Menyusu Dini (IMD) di Nasrul Ummah Lamongan tahun 2019

\begin{tabular}{llcc}
\hline No & Kategori & F & \% \\
\hline 1. & Baik & 1 & 4,2 \\
2. & Cukup & 10 & 41,7 \\
3. & Kurang & 13 & 54,1 \\
\hline & Total & $\mathbf{2 4}$ & $\mathbf{1 0 0}$ \\
\hline
\end{tabular}

Tabel 4. Menunjukkan bahwa sebagian besar berpengetahuan kurang dan sebagian kecil berengetahuan baik tentang Inisiasi Menyusu Dini (IMD)

\section{PEMBAHASAN}

Pada bab ini akan disajikan hasil penelitian yang telah dilakukan untuk mengetahui gambaran pengetahuan tentang Inisiasi Menyusu Dini (IMD) Ibu Hamil Trimester II dan III di RSI Nasrul Ummah Lamongan

Berdasarkan tabel 4 didapatkan ibu hamil trimester II dan III yang memiliki pengetahuan kurang tentang Inisiasi Menyusu Dini (IMD). Pengetahuan yang kurang tentang Inisiasi Menyusu Dini (IMD) disebabkan oleh beberapa hal yaitu umur, pendidikan, dan pekerjaan ibu hamil trimester II dan III.

Menurut Budiman (2013) faktor yang dapat memengaruhi pengetahuan adalah umur. Umur mempengaruhi daya tangkap dan pola pikir seseorang, sehingga pengetahuan yang diperoleh juga akan semakin membaik dan bertambah. Dengan bertambahnya umur seseorang, akan terjadi perubahan aspek fisik dan psikologis (mental). Bertambahnya umur maka lebih banyak informasi yang didapat 
serta pengalamannya juga lebih banyak. Hasil penelitian ini hampir setengah responden berumur 26-30 tahun, dimana pada usia tersebut termasuk usia dewasa. Pada kenyataannya banyak yang memiliki pengetahuan kurang. Hal itu disebabkan karena tidak di imbangi dengan informasi yang adekuat. (Notoadmojo,2011)

Selain umur, faktor lain yang dapat mempengaruhi ibu hamil trimester II dan III adalah pendidikan. Berdasarkan tabel 2 menunjukkan bahwa hampir sebagian ibu hamil timester II dan III berpendidikan SMA/SMK/ MA dan sebagian kecil SMP/MTS. Pendidikan merupakan sebuah proses perubahan sikap dan perilaku seseorang atau kelompok, pendidikan juga dapat mendewasakan manusia melalui upaya pengajaran dan pelatihan. Semakin tinggi pendidikan seseorang maka akan semakin mudah orang tersebut untuk menerima informasi Budiman (2013). Penting bagi ibu mengetahui manfaat dan aplikasi tentang Inisiasi Menyusu Dini (IMD). Semakin tinggi pendidikan ibu hamil trimester II dan III maka akan semakin banyak pengetahuan untuk memahami pentingnya Inisiasi Menyusu Dini (IMD), dan semakin mudah menerima informasi, pada akhirnya makin banyak pengetahuan yang dimiliki. Sebaliknya semakin rendah tingkat pendidikan, maka sulit bagi ibu untuk menangkap informasi maupun ide-ide tentang Inisiasi Menyusu Dini (IMD).

Karakteristik responden berdasarkan pekerjaan diperoleh hasil hampir setengah ibu hamil trimester II dan III bekerja sebagai ibu rumah tangga dan sebagian kecil sebagai mahasiswa. Pekerjaan sangat berkaitan dengan lingkungan yang dapat mempengaruhi terhadap proses masuknya pengetahuan ke dalam individu yang berada dalam lingkungan tersebut. Lingkungan pekerjaan yang baik akan berpengaruh terhadap pengetahuan ibu hamil tentang Inisiasi Menyusu Dini (IMD). Ibu hamil yang berprofesi sebagai ibu rumah tangga tidak banyak interaksi dengan lingkungan yang memberikan banyak pengetahuan tentang Inisiasi Menyusu Dini (IMD) dikarenakan ibu kesehariannya banyak menghabiskan waktu dirumah mengurus rumah tangga. Sebaliknya ibu yang bekerja diluar rumah akan lebih banyak mendapatkan informasi dari lingkungan pekerjaan terutama informasi langsung yang didapat dari rekan kerja berdasarkan pengalaman tentang Inisiasi Menyusu Dini (IMD).

Hasil penelitian menunjukkan bahwa pengetahuan ibu hamil trimester II dan III tentang Inisiasi Menyusu Dini (IMD) di RSI Nasrul Ummah Lamongan adalah sebagian besar berpengetahuan kurang dan sebagian kecil berpengetahuan baik. Pengetahuan manusia sebagian besar diperoleh melalui mata dan telinga. Semakin tinggi pengetahuan ibu hamil trimester II dan III tentang Inisiasi Menyusu Dini (IMD) maka semakin bisa menerapkan pada saat melahirkan. Begitu juga sebaliknya semakin rendah pengetahuan dapat menyebabkan ibu hamil tidak menerapkan Inisiasi Menyusu Dini (IMD) pada bayi yang dilahirkannya dikarenakan tidak memahami bahkan mengetahui pentingnya Inisiasi Menyusu Dini (IMD). Semakin banyak ibu hamil mendengar, melihat, maka akan semakin besar prosentase untuk melakukanya IMD ke bayinya. Akan tetapi apabila ibu tidak pernah sama sekali mendengar dan melihat Inisiasi Menyusu Dini (IMD) maka dapat dipastikan akan mengalami ketidaktahuan dan kesulitan menerapkan Inisiasi Menyusu Dini (IMD). Menurut Soekidjo Notoatmodjo (2011) pengetahuan merupakan hasil dari tahu, dan ini terjadi setelah orang melakukan penginderaan terhadap suatu objek tertentu. Penginderaan terjadi melalui pancaindra manusia, yaitu indera penglihatan, pendengaran, penciuman, rasa dan raba.

Selain faktor yang sudah diteliti oleh penulis ada beberapa faktor lain menurut Budiman (2013) yang dapat mempengaruhi pengetahuan adalah sosial budaya, ekonomi, lingkungan, dan informasi. Namun karena keterbatasan peneliti maka peneliti hanya membatasi pada faktor umur, pendidikan, dan pekerjaan.

\section{KESIMPULAN}

Berdasarkan hasil penelitian dan pembahasan serta tujuan penelitian tentang gambaran pengetahuan tentang Inisiasi Menyusu Dini (IMD) Ibu Hamil Trimester II dan III di RSI Nasrul Ummah Lamongan dapat disimpulkan bahwa sebagian besar responden mempunyai pengetahuan kurang tentang Inisiasi Menyusu Dini (IMD). 


\section{DAFTAR PUSTAKA}

Adam, A. A. 2016. Pemberian Inisiasi Menyusu Dini Pada Bayi Baru Lahir. Jurnal Kesehatan MANARANG, 76-82.

Budiman, R. 2013. Kapita Selekta Kuesioner Pengetahuan dan Sikap dalam Penelitian Kesehatan. Jakarta: Salemba Medika.

Iis S. 2010, Faktor-faktor yang Berhubungan dengan Pemberian ASI dalam Satu Jam Pertama Setelah Lahir di Kabupaten Garut Provinsi Jawa Barat (Analisis Survey Data Dasar Pengembangan Model Pelayanan Kesehatan Neonatal Esential di Kabupaten Garut Jawa Barat, Tahun 2007), Jurnal Kesehatan Media Litbang Kesehatan Vol XX No 2 Tahun 2010

Lau Y, H. T.-L. 2015. Maternal, Infant Characteristics, Breastfeeding Techniques, and Initiation: Structural Equation Modeling Approaches. PLOS One, 1-17.

Mahmud, S. H. 2013. Pengaruh Pendidikan Insiasi Menyusu Dini Terhadap Pengetahuan Ibu Hamil Trimester III . Jurnal Stikes Nani Hasanuddin Makassar Vol. 2 No. 5, 105-110.

Notoadmojo, S. 2011. Kesehatan Masyarakat Ilmu dan Seni. Jakarta: Salemba Medika.

Novianti. Rizkianti, A. 2014. Pemberian Asupan Prelakteal Sebagai Salah Satu Faktor Kegagalan ASI Eksklusif Pada Pekerja Buruh Industri Tekstil di Jakarta. Jurnal Kesehatan Reproduksi Vol. 5 No. 1, 23-36.

Saleha, S. 2009. Asuhan Kebidanan Pada Masa Nifas. Jakarta: Salemba Medika.

Tamara, Marina. 2011. Hubungan Inisiasi Menyusu Dini dengan keberhasilan ASI Eksklusif dan faktor-faktor yang mempengaruhi. Indonesian Journal of Obstetrics and Gynecology.Vol.35

UNICEF, W. 2018. Capture the Moment Early initiation of breastfeeding : The best start for every newborn. New York: UNICEF. 